\title{
FURTHER INFORMATION ON THE PREHISTORIC REPRESENTATIONS OF HUMAN HANDS IN THE CAVE OF GARGAS
}

by

\section{ALEX HOOPER*}

\begin{abstract}
This paper amends and adds recent information to Paul A. Janssens' earlier article on the prehistoric paintings of human hands in the cave of Gargas, France. ${ }^{1}$ Possible diagnoses for the deficiencies found in many of the hand pictures, and some nonmedical theories of explanation, are reviewed. It is concluded that the hands used as stencils were mutilated and that the images were deliberately placed within the cave and were not the by-products of some other activity.
\end{abstract}

In 1957 Paul A. Janssens presented an article concentrating on the many "mutilated" hands depicted on the walls in the cave of Gargas, near Aventignan, Hautes-Pyrénées, France. Since that time, much work has been done, notably by Sahly ${ }^{2}$ and by Barrière, ${ }^{3}$ towards making a complete inventory of the art in this cave, including the animal pictures, signs of unknown significance, and the representations of hands.

Of the 231 paintings of hands, both in negative outline and positive imprint, 114 show mutilations of one or more fingers, and only ten are definitely complete with no deficiency in the number of finger joints. The remaining 107 hand pictures, which may possibly be 30,000 years old, have not been well enough preserved through the millennia to allow a decision as to whether they were mutilated or not.

Janssens discussed possible diagnoses of the mutilated hands, favouring Raynaud's disease on account of the cold climatic conditions prevailing during the Ice Age, the small size of many of the hands (possibly being young women's hands), and the fact that this disease may be hereditary (assuming that the hands belonged to one extended kin group). Frostbite alone probably would not account for the many mutilations shown, otherwise it would seem likely that similar mutilations would be depicted more frequently through the range of caves decorated during the Upper Palaeolithic period in France and Spain. Out of the dozen or so caves containing hand pictures dated to that period, only two show mutilations: one is the cave of Tibiran in the same mountain as Gargas; the other is far away at Maltravieso in Spain and displays a

\footnotetext{
*Alex Hooper, 88 Poplar Court, Gap Road, London SW19 8JW.

1 Paul A. Janssens, 'Medical views on prehistoric representations of human hands', Med. Hist., 1957, 1: $318-322$.

2 Ali Sahly, Le problème des mains mutilées dans l'art préhistorique, Thèse de Doctorat des Lettres (Toulouse), Tunis, 1969.

3 Claude Barrière, L'art pariétal de la grotte de Gargas, Parts I and II, Oxford, British Archaeological Reports, 1976.
} 


\section{Short Articles}

different style of mutilation. Other diagnoses that Janssens considered, but rejected for various reasons, are acute arteritis, syphilitic arteritis, arteriosclerosis, embolism, diabetic gangrene, and obstructive thromboangiitis. To this list Sahly adds ainhum (hereditary, but affecting only the fifth finger and mainly known amongst male Negroes in the tropics), leprosy (unlikely, because the metacarpals do not seem to be affected at Gargas), acrocyanosis, and several afflictions such as chilblains and rheumatism.

Janssens reviewed some evidence concerning ritual or votive hand mutilations amongst modern tribal peoples and, assuming that the Gargas artists had painted the hands with individual fingers missing randomly, came to the conclusion that the Gargas hands had not been subjected to votive amputation because humans typically value their thumbs very highly and so do not normally sacrifice them. However, the latest information is that the fingers are not missing randomly, since none of the clearly preserved hands shows absence of the thumb. Thus, Janssens' objection to ritual amputation may no longer be sustained on this score and non-medical explanations may still be considered.

Perhaps the most elaborate non-medical explanation that uses ethnographic information is Andre Leroi-Gourhan's theory. 4 This suggests that the configurations of the finger mutilations might resemble the code of silent hand signals used by certain Kalahari Bushmen hunters to communicate information about the presence of game. Three folded middle fingers, for instance, would indicate "gazelle", just the middle finger folded means "giraffe", while an open hand with no fingers bent means "monkey". As animals form the main subjects of Palaeolithic art, this theory at least represents a possibility.

Such an explanation, if feasible, would raise the question of how the missing fingers were effected in the drawings. Were they the results of actual mutilation of finger joints, or could they be produced by flexion of the joints so that the "missing" finger was bent away while the paint was applied? The latter suggestion might be possible for some cases, but it is known from the presence of impressions of human limbs on hardened mud at Gargas that at least some of them displayed stumps instead of complete fingers. 5

It is not always easy to be certain whether any particular hand image is of a right hand palmar surface up or of a left hand dorsal surface up and vice versa, ${ }^{6}$ or whether some deliberate distorting technique was used. Experimental work on reconstructing the Gargas pictures is currently being carried out by prehistorians to find the visual effects of various brushing, spraying, and drawing methods on hands in various positions on limestone surfaces. The results of one set of tests by Martin Wildgoose suggest that hands were actually mutilated and not somehow contorted during painting. ${ }^{7}$

\footnotetext{
4 André Leroi-Gourhan, 'Les mains de Gargas. Essai pour une étude d'ensemble', Bull. Soc. préhist. fr., 1967, 64: 107-122.

5 Barrière, op. cit., note 3 above, p. 81.

6 Peter J. Ucko and Andrée Rosenfeld, Palaeolithic cave art, London, World University Library (Weidenfeld \& Nicolson), 1967, pp. 99-100.

7 Evan Hadingham, Secrets of the Ice Age. The world of the cave artists, New York, Walker, 1969, pp. 146-148.
} 


\section{Short Articles}

One thing does seem clear: the people responsible for the Gargas hands were not primarily concerned with colouring their hands red, black, brown, yellow, or white, while merely using the cave walls as a convenient support. This may be observed from the striking topographical positions within the cave of many of the hands - e.g., within a niche in the rock, which forms an effective frame for the image, ${ }^{8}$ or at the top of a steep, slippery slope. It is reasonable to conclude, therefore, that the hand images were deliberately positioned within the cave and were not merely the accidental by-products of some other activity.

Finally, readers may wish to visit the cave of Gargas. This is possible without prior arrangement on any day of the week during daylight hours in spring and summer.

8 Janssens, op. cit., note 1 above, fig 2.

\section{News, Notes and Queries}

\section{ROYAL COLLEGE OF PHYSICIANS OF LONDON}

An exhibition entitled "Modern Archives at the RCP" is on display until 23 May 1980 in the College Library (11 St. Andrew's Place, London NW1). It includes autograph letters, case-notes, legal documents, plans, reports, etc. A printed catalogue of the exhibits is available.

\section{EUROPEAN SOCIETY FOR THE HISTORY OF OTORHINOLARYNGOLOGY}

The purpose of this newly founded society is to investigate and to preserve documents concerning the development of otorhinolaryngology from antiquity to the present day. The founding members are: J. Willemot, M.D. (Belgium); W. Pirsig, M.D. (West Germany); E. H. Majer, M.D. (Austria); V. Micheli Pelligrini, M.D. (Italy); J. Michel, M.D. (France). For further information, please contact J. Michel, M.D., 4 Avenue J. Perrot, 38000 Grenoble, France.

\section{CENTER FOR PHOTOGRAPHIC IMAGES OF MEDICINE AND HEALTH CARE}

To stimulate the development of materials for teaching the history of medicine and health care using photographs, this Centre will award several small grants to historians and educators in medicine and other health professions. The grants are intended to support research into photographic sources, duplication of photographic images, and production of a written text to accompany a unified collection of slide copies of the images selected.

Proposals must be submitted by 30 July 1980 . Full information from: Center for Photographic Images, Dept. of Community and Preventive Medicine, Health Sciences Center, State University of New York at Stony Brook, N.Y. 11794, U.S.A. 